\title{
NEURAL NETWORKS MODELLING OF MUNICIPAL REAL ESTATE MARKET RENT RATES
}

\author{
Andrzej Muczyński, Ph.D., Eng. \\ University of Warmia and Mazury in Olsztyn \\ The Faculty of Geodesy, Geospatial and Civil Engineering \\ Department of Real Estate Resources \\ Prawocheńskiego Street 15, 10-724 Olsztyn, Poland \\ e-mail:amucz@uwm.edu.pl
}

Marek Walacik, Ph.D., Eng.

University of Warmia and Mazury in Olsztyn

The Faculty of Geodesy, Geospatial and Civil Engineering

Department of Land Management and Regional Development

Prawocheńskiego Street 15, 10-724 Olsztyn, Poland

e-mail: marek.walacik@uwm.edu.pl

Received 19 November 2015, Accepted 16 November 2016

\begin{abstract}
This paper presents the results of research on the application of neural networks modelling of municipal real estate market rent rates. The test procedure was based on selected networks trained on the local real estate market data and transformation of the detected dependencies - through established models - to estimate the potential market rent rates of municipal premises. On this basis, the assessment of the adequacy of the actual market rent rates of municipal properties was made. Empirical research was conducted on the local real estate market of the city of Olsztyn in Poland. In order to describe the phenomenon of market rent rates formation an unidirectional three-layer network and a network of radial base was selected. Analyses showed a relatively low degree of convergence of the actual municipal rent rents with potential market rent rates. This degree was strongly varied depending on the type of business ran on the property and its' social and economic impact. The applied research methodology and the obtained results can be used in order to rationalize municipal property management, including the activation of rental policy.
\end{abstract}

Keywords: municipal real estate stock management, artificial neural networks, property rent market 


\section{Introduction}

The rational management of municipal properties is a complex issue under current conditions. This applies particularly to municipal resources because of high functional and locational diversity of these objects and requires a flexible approach in the renting process based on the proper balancing of social and economic interest of the municipality as the owner (Kemp, Kofner, 2010). Some of the municipal resources are used in order to execute particular municipal public responsibilities that include for example cultural (cultural centers), educational (schools, kindergartens) or health care (health clinics) ones (Crook, Kemp, 2014).

In the municipal property resources there are also premises that are rented for commercial activities - purposes outside the public sphere. Such premises comply with the features typical of commercial buildings and their rental income is a significant supplement of budget revenues (Kemeny, 1995). In this context, one of the major problems of municipal property management of resources premises is creating an appropriate level of rent (Morris, 2009). The determination of appropriate rental rate should include - on the one hand - the type of activity that will be ran on the property, the advantages of the location and properties' technical characteristics, on the other hand, local market trends (Kemeny, 2005).

The main aim of the work was to use artificial intelligence methods to determine market models of municipal property rent rates. It was assumed, since neural networks use has already been proposed in determining property values (Wisniewski, 1999), willingness to pay to reduce road traffic annoyance (Bravo-Moncayo et al., 2017), describe the dynamics of the daily average temperature accurately in the context of weather derivatives pricing (Alexandridis et al., 2017) and many others, that neural networks were useful tools for describing (modelling) the local real estate rental market due to their ability to detect, learn and memorize multiple market dependencies and using them to perform particular tasks. In the first stage of the study selected types of neural networks were used to encode the relationships and dependencies that determine private property rent rates. Then certain regularities were transferred - through the learned network - to determine the model for municipal rent rates. A comparison of actual rent rates with their market models allowed for a market adequacy assessment of rental rates in selected groups of municipal properties.

\section{Research methodology}

Neural networks were created as a result of research conducted in the field of artificial intelligence predominately on the construction of models of structures occurring in the brain. 
They were aimed at mimicking the biological characteristics of the nervous system that may be technically useful. A catalogue of such features include mainly the resistance of biological systems to damage and their extraordinary ability to learn (StatSoft, 2001) (Bishop, 1995) (Witkowska, 2002) (Osowski, 1996).

Artificial neural networks, as a method of artificial intelligence, has the ability to analyse large amounts of information in a fast and parallel way, where each variable can be presented with the use of multiple levels of value. They show the ability to repeat particular behaviour during the learning process, on the basis of that draw conclusions, memorize and use them as well as generalize. The particular features of these networks make that they can be used to analyse the processes taking place in the real estate market (Wisniewski, 1999), including solving both regressive (Muczyński, Kołek, 2007) and classification issues (Muczyński, 2009).

The research methodology was based on the assumption that the process of modelling market rent rates would be implemented in the selected area of the local rental market for the properties having a utilitarian function. This area should be characterized by the coexistence of premises owned by the municipality (rented at the "municipal" rates) and similar to them - in terms of the utility value and location - premises of private owners (rented at market rates).

The essence of the application of neural networks is to use data from a set of lease transactions of private property to detect a network, learn empirical regularities occurring on the local rental market, and then pass the input to a trained network of relevant attributes premises of the municipality. In this way, neural networks modelled the estimates of the market rent rate of municipal properties that is the rate that could be potentially achieved if these properties were rented by private owners.

Empirical studies were conducted in the area of the local rental market of the city of Olsztyn (Poland). The data describing the individual lease agreements concerned the rates achieved in 2015 (Walacik, 2016). At the beginning of the analysis not only features including location and technical details of municipal properties were examined but also other attributes available in the private property registers. After initial recognition of the research subject, further analysis was carried out according to the procedure outlined below.

\subsection{Data preparation}

After collecting the raw data characterizing objects and rental rates in both private and municipal property market sectors the first methodological problem was predicting a set of variables that should be involved in the process of training the network and determination of the necessary number of observations. While choosing the set of attributes that describe the market 
rent rates one used the available literature of the subject (Masters, 1996), the results of previous studies as well as the availability and reliability of the acquired data.

The initially chosen set of variables that could potentially create a neural network input vector was validated with the use of methods analysing the impact of individual variables on the dependent variable - market rent rate per month. Practically the rolling regression method was used, genetic algorithms and the method of sensitivity analysis. The calculations were performed with the use of STATISTICA Neural Networks StatSoft Poland.

A fixed set of input variables and their quantification is provided in Table 1.

Table 1. List of independent variables selected for the analysis and quantification

\begin{tabular}{|c|l|l|}
\hline No. & \multicolumn{1}{|c|}{ Type of independent variable } & \multicolumn{1}{c|}{ The way of quantification } \\
\hline 1 & Distance of the property form the city center & $\begin{array}{l}\text { Distance in kilometres, measured in a straight line from } \\
\text { property to the city center }\end{array}$ \\
\hline 2 & The size (area) of property & Square metres \\
\hline 3 & City location zone & $\begin{array}{l}\text { The division of the city into two zones by proper resolution } \\
\text { of the location of the City of Olsztyn } \\
1-\text { the first zone, } 2 \text { - the second zone }\end{array}$ \\
\hline 4 & Type of business run on the property & $\begin{array}{l}\text { Division of properties according to the type of business run } \\
\text { on it: trading, services, warehousing and public utilities }\end{array}$ \\
\hline
\end{tabular}

Source: own elaboration.

The final step in the preparation of the data was to divide the data set into subsets: learning set, validation set and test set (Tadeusiewicz, 1993). For this purpose the designated automatic program designer was used that divided subsets, respectively in the proportion of $2: 1: 1$.

\subsection{Design and selection of the appropriate structure of artificial neural networks}

Network design, after particular individual variable selection, requires the implementation of a sequence of several further steps. First, it is necessary to choose the initial network structure and then iteratively to perform a series of experiments with any network configuration maintaining the best configuration in terms of the validation error (StatSoft, 2001). The number of experiments required for the best network selection is relatively big. In order to avoid errors resulting from stopping the algorithm at a local minimum, it is recommended to carry out several experiments with every possible network structure. If the results of the experiment indicate a lack of network learning, one ought to add new hidden neurons or a whole new hidden layer. However, in a situation where the experiment indicates network overlearning (validation error starts to rise significantly before reaching a satisfactory level of training the network); one ought to remove a number of hidden neurons (or their layers). After finding a satisfactory 
network configuration one should perform sampling in order to get a new network with a fixed configuration.

In the first phase of the study network models of an unidirectional-layer, three-layer, four-layer, linear and radial basis function were trained. The groups of weights were randomly initialized from -1 to 1 range. The learning parameters were selected with the use of iterative approximations. In order to optimize the algorithms back propagation, conjugate gradient and the Levenberg-Marquardt method were used.

After testing dozens of different models, it was found that the model layer perceptron (MLP), radial basis function model (RBF) and some collections of these networks described the phenomenon in the best way. Selected types of networks characterized the best architecture of the analysed ones and also their process of learning and testing was relatively short. Detailed assumptions on the selection of particular networks used for Olsztyn real estate rent rate modelling were presented by Kołek (Kołek, 2006).

\subsection{Evaluation of the results}

In order choose the best structure of the network estimators one can use the standard gauges, available in different software, namely: model fit error for the training and validation (elimination of network overtraining), as well as the ratio of deviation and coefficient of model fit (correlation criterion).

After determination of the modelled market rent rates in a group of municipal properties with the use of properly trained neural networks one could proceed to the final stage of this research - the assessment of the adequacy of the actual market rent rates of municipal properties. The assessment was based on the measurement of the degree of conformity of the actual municipal rent rates with modelled market rent rates determined with the use of a neural network. As a measure of compliance the following indicator of the adequacy of market rent $A_{2}$ was used (Muczyński, 2006):

$$
A_{2}=\left(1-\frac{R(C k)-C k}{R(C k)}\right) \times 100 \%,
$$

where:

$A_{2} \quad$ - adequacy ratio of municipal market rents (\%),

$C k$ - the actual municipal rent rate $\left(\mathrm{PLN} / \mathrm{m}^{2}\right)$,

$R(C k)$ - modelled municipal rent rate $\left(\mathrm{PLN} / \mathrm{m}^{2}\right)$. 
Indicator $A_{2}$ was defined in such a way that it expressed the relative degree of compliance of the actual municipal rent rate $C k$ with its' market model $R(C k)$. The modelled rent rate of particular property is determined by the attributes (from Table 1) to the input of trained neural network models. The variation of $A_{2}$ ranged from 0 to $100 \%$. It reaches the maximum value when the actual municipal rent rate reaches the level of potential market rent - determined by the neural model. On the other hand, the lower limit of this ratio (at $0 \%$ ) is purely theoretical, as there may be a drop in municipal rent rate to zero.

\section{Research results}

As a result of the modelling procedure from a group formed in the course of learning the top five network models were selected. Table 2 below shows the basic characteristics of these models.

Table 2. Basic characteristics of achieved neural network models

\begin{tabular}{|l|c|c|c|c|c|c|c|}
\hline Network type & $\begin{array}{c}\text { Training } \\
\text { quality }\end{array}$ & $\begin{array}{c}\text { Quality } \\
\text { of validation }\end{array}$ & $\begin{array}{c}\text { Testing } \\
\text { quality }\end{array}$ & $\begin{array}{c}\text { Training } \\
\text { error }\end{array}$ & $\begin{array}{c}\text { Validation } \\
\text { error }\end{array}$ & $\begin{array}{c}\text { Testing } \\
\text { error }\end{array}$ & Training/components \\
\hline 1 & 2 & 3 & 4 & 5 & 6 & 7 & 8 \\
\hline MLP 4:7-15-1:1 & 0.75652 & 0.87652 & 0.73412 & 0.20048 & 0.22312 & 0.14356 & BP100, CG24b \\
\hline MLP 4:6-20-1:1 & 0.78542 & 0.75231 & 0.81243 & 0.12342 & 0.10635 & 0.11564 & BP621b \\
\hline MLP 4:6-8-1:1 & 0.72134 & 0.76423 & 0.82654 & 0.17453 & 0.18073 & 0.20132 & BP100, CG20, CG9b \\
\hline Wyj. 3:[5]:1 & 0.75233 & 0.80154 & 0.78765 & 0.12131 & 0.14563 & 0.13463 & $1-5$ \\
\hline
\end{tabular}

Source: own study.

Network type shows the characteristics of the structure of the resulting model. The recording format is as follows: $<$ type $><$ input $><$ Layer $1>-<$ Layer $2>-<$ Layer3 $><$ go $>$. For example, the code MLP4: 6-6-1: 1 is a multilayer perceptron with four input variables and one output, having three layers - respectively with six neurons in the first two layers and one neuron in the latter. As the table shows, the task of predicting market rent is best filled by the four-way multilayer network (MLP). Qualified to set the fifth model (designated as "Wyj.") represents the network team consisting of a combination of linear network, the two MLP networks and two RBF networks.

Each of the selected networks has one hidden layer, which includes a number of hidden neurons, respectively, from 2 to 20 (MLP networks) and from 11 to 38 (RBF networks). 
In columns 2-4 of Table 2 the network quality measures identified through the process of learning for the training set, validation and test are shown. Validation meters were used as the basis for the best network selection. In the case of continuous variables (network regression) the correct measure of network quality is the quotient of standard deviations. This quotient is a measure of model quality improvement and its value should be smaller than 1 . The better the network is the closer the ratio deviation is to zero.

The selected network presented the lowest ratios of deviations that were achieved in the learning process. The next column of Table 2 presents the network errors obtained in the course of learning in the subsets of the data. These errors are determined on the basis of the errors calculated with the use of an adopted error function, which was the sum of the squared differences between the actual value and the resulting output. Corresponding validation errors and test subsets are comparable and relatively low.

This means that the selected network generalizes the knowledge contained in the case of learners well. In the last column of Table 2 the symbolic descriptions of the learning strategies of individual networks (learning algorithms) were shown. The codes of algorithms were shown with, numbers of iterative algorithms periods, and optionally the codes of best network selection methods. For example, the code CG24b means that the conjugate gradient algorithm (CG) was used, then the best network (b) was selected, and it was obtained in 24 era.

In turn, the symbol BP100CG24b means 100 epochs of back-propagation learning (BP) followed by the 24 era conjugate gradient method learning when the network began to overlearn. The established models of neural networks can be exploited for any input values. The studies examined the network input data characterizing commercial properties in Olsztyn. The input values included 340 municipal properties. A number of cases (units) were eliminated from the calculation due to information gaps. Moreover, in the absence of data on the actual rent rates of certain premises the average rent rates were applied.

Before starting the networks for new data set test of municipal properties, the properties were divided into four types according to the kind of business ran on the property. Such a division aimed at improving the transparency of the studied phenomenon study and interpretation of the results. Consequently, the modelled municipal market rent rates were determined separately for each of the selected groups.

During the calculation the groups were assigned two or three network models (of the five shown in Table 2) relatively best mapping trends prevailing in the market sector. The empirical results of modelling the municipal market rent rates of commercial and public utility functions are shown in Figures 1 and 2. These figures show that in both groups of properties real rent 
rates significantly different from the potential market rates, modelled with the use of neural networks. This pattern also applies to other types of properties. After having analysed all of the four properties, it has been concluded that the smallest discrepancy between the actual rent rate and the market one occurred in the group of commercial properties.

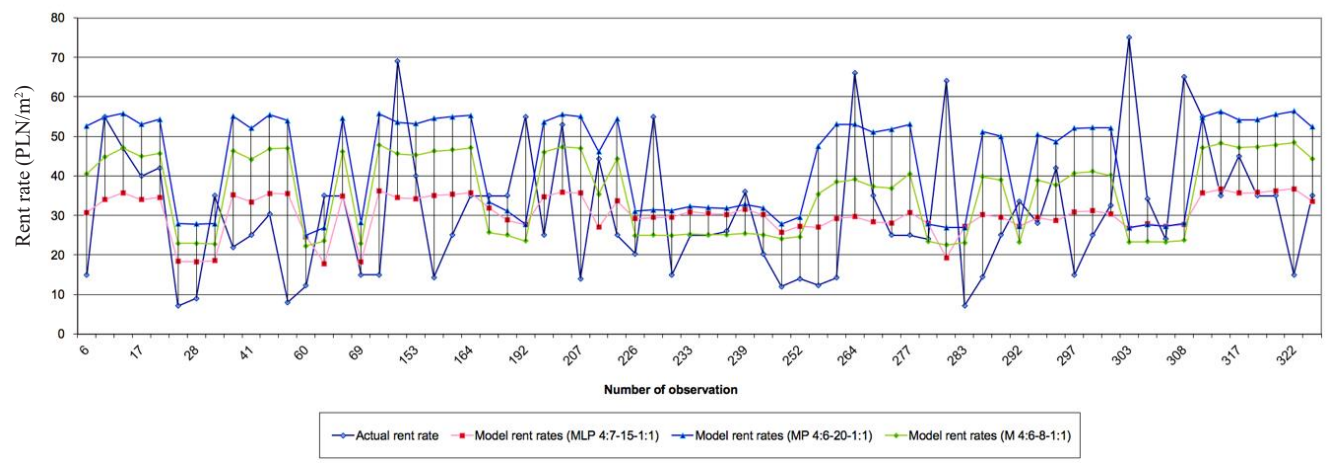

Figure 1. Actual and modelled commercial property rent rates from the city of Olsztyn resources established with the use of selected neural networks

Source: own study.

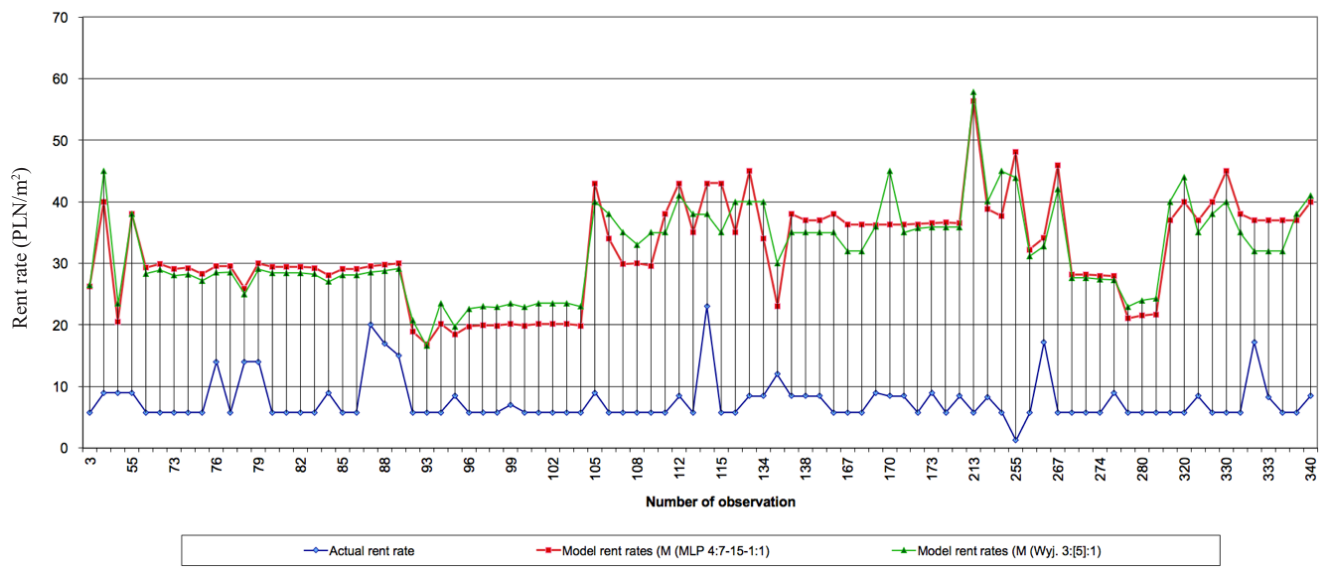

Figure 2. Actual and modelled public utility property rent rates from the city of Olsztyn resources established with the use of selected neural networks

Source: own study.

Three multilayer one way networks established for this group of properties average rental rate at the level of $36.63 \mathrm{PLN} / \mathrm{m}^{2}$. If we take into account the actual average rent rate that equals 
30.37 PLN $/ \mathrm{m}^{2}$ modelled rates are higher than the actual ones on average 1.5. The fixed ratio of average size, however, is a big simplification. It should be noted that in certain cases the rent rate of commercial properties assigned by each of the three networks was different. Sometimes the actual rent turned out to be even higher than the one obtained from the model.

Relatively the lowest average rate of real rent - at the level of $7.64 \mathrm{PLN} / \mathrm{m}^{2}$ was characterized by a group of public utility municipal properties (Figure 2). The application of the MLP networks of the four variables and the network team of three variables led to an average rate of the modelled market rent level of $-31.99 \mathrm{PLN} / \mathrm{m}^{2}$.

The results show the greatest discrepancy of between the actual and the market lease rent in the group of public utility properties - they were rented more than seven times cheaper than the market rent rate. It was noted further that the two network models have attributed particular properties to this type of very similar rates of potential market rent. This may be due to the fact that most public premises have very similar location advantages.

In the last phase of the study the assessment of the adequacy of the actual market rent rates of municipal properties was made. For this purpose, the indicator $A_{2}$ was used. The obtained values of this index are shown in Table 3. It was considered that an objective assessment of the adequacy of market rent rates in the analysed groups requires a detailed analysis of the $A_{2}$ distribution parameters indexes in the form of location measures and dispersion.

The data in Table 3 confirm that the actual rent of the analysed types of premises has a varied degree of market adequacy. This clearly shows the main measure of the position for which one adopted the arithmetic mean value of the indicator set $A_{2}$ in the distinguished types of properties.

The highest degree of convergence of market rents showed commercial properties, for which the mean adequacy market - depending on the model network - ranged from 77.3 to $104.3 \%$.

Table 3. Evaluation of market rental adequacy for certain types of properties from the city of Olsztyn resources

\begin{tabular}{|l|c|c|c|c|c|c|}
\hline \multirow{3}{*}{ The property type } & \multicolumn{6}{|c|}{ Characteristics of value adequacy rate distribution $-A_{2}(\%)$} \\
\cline { 2 - 7 } & $\begin{array}{c}\text { arithmetic } \\
\text { average }\end{array}$ & $\min$ & $\max$ & spread & $\begin{array}{c}\text { standard } \\
\text { deviation }\end{array}$ & $\begin{array}{c}\text { coefficient } \\
\text { of variation }\end{array}$ \\
\hline \multirow{3}{*}{ Commercial } & 104.3 & 22.5 & 331.3 & 308.7 & 0.51 & 0.78 \\
\cline { 2 - 7 } & 77.1 & 14.8 & 278.9 & 264.1 & 0.42 & 0.69 \\
\cline { 2 - 7 } & 93.8 & 17.0 & 322.2 & 305.2 & 0.49 & 0.72 \\
\cline { 2 - 7 } Public utilities & 25.2 & 2.58 & 67.8 & 65.2 & 0.12 & 0.48 \\
\hline
\end{tabular}

Source: own study. 
By far the lowest level of the adequacy of the market was shown in public utility rent rates, where the average rate of $A_{2}$ used network models designated at the level of 24.9 and $25.2 \%$. The obtained levels of $A_{2}$ shows that its' rate is determined by the kind of business ran on the property.

Considering the measurement value dispersion $A_{2}$, it should be noted that the range of variation of this ratio is very large in all types of units. The extreme values and their so called spread show that. A very large dispersion - expressed by the spread - characterizes the adequacy ratios of commercial (264.0-308.7\%) and public utilities (65.2-67.3\%) rates. This points to the fact that the high volatility of some of the commercial and service rents exceeded their potential market level. Mutual relations between the absolute value of the degree of dispersion adequacy ratio in the studied types of venues have been confirmed as values standard deviation. In turn, the relative dispersion, as measured by the coefficient of variation, showed the relatively small scale of the differences in the dispersion of market indicators adequacy of the rental units in the studied groups.

\section{Conclusions}

The carried out analysis allowed drawing the following conclusions:

1. It was found that the phenomenon of market rent formation was best described by a oneway three-layer network and the networks of radial basis function. These structures showed the lowest error fit, and also the duration of their training was relatively short. When determining the set of input variables into account the actual characteristics taken into account were the renting premises of the Olsztyn resource. Despite the simplicity of architecture, some networks have demonstrated the high ability to generalize and supplement the information in cases of a lack of sufficient data from the market.

2. The effects of artificial neural networks as a tool for modelling municipal property market rate rents, shows that artificial intelligence methods can be successfully used for solving regression real estate market problems. With limited theoretical knowledge of researchers these were able to create rational rent rate models that took into account the conditions of the local rental market. The degree of accuracy to identify potential market rents received by the network was satisfactory, and the procedure for their modelling was user friendly.

3. The results confirmed the desirability of dividing this resource into four functional groups. The highest rental interval showed commercial properties, the lowest public utility ones, and warehouses occupied intermediate positions. In reverse order the discrepancies between 
actual and potential rent rates were noticed. These relationships strongly varied depending on the type of business ran on the property and its' social and economic impact.

4. The models of neural networks were attributed to individual municipal properties different rate rates. This indicates the existence of "natural" imperfections of the real estate market phenomenon manifested by the "blurring" of the potential market rent for the same objects. From this point of view, a point estimation of rent should be replaced by the range estimation. These effects can be achieved with methodology based on the use of artificial intelligence.

5. The calculated adequacy ratios confirmed the thesis of a relatively low degree of convergence of the actual municipal rents rates with market rent rates. This demonstrates the active passive rental policy of the city of Olsztyn. Too low rents have a negative effect on the ability to maintain economic equilibrium in the municipal economy resources resulting with a lack of funds for proper management and technical maintenance of resources, especially for repairs and investment.

6. The realized research forms a useful tool for policy change in municipal rental rates.

\section{References}

Alexandridis, A.K., Kampouridis, M., Cramer, S. (2017). A comparison of wavelet networks and genetic programming in the context of temperature derivatives. International Journal of Forecasting, 33 (1), 21-47.

Bishop, C.M. (1995). Neural Networks for Pattern Recognition. Clarendon Press.

Crook, T., Kemp, P.A. (eds) (2014). Private Rental Housing. Cheltenham: Edward Elgar.

Kemp, P.A., Kofner, S. (2010). Contrasting varieties of private renting: England and Germany. International Journal of Housing Policy, 10 (4), 379-398.

Kemeny, J., Kersloot, J., Thalmann, P. (2005). Non-profit housing, influencing, leading and dominating the unitary rental market: Three case studies. Housing Studies, 20 (6), 855872 .

Kemeny, J. (1995). From Public Housing to the Social Market: Rental Policy Strategies in Comparative Perspective. London: Routledge. 
Kołek, M. (2006). Ocena rynkowej adekwatności czynszu najmu w gminnych zasobach lokali uzytkowych miasta Olsztyna. Master's thesis performed under the direction of Ph.D. Ing. Andrzej Muczynski. Wydział Geodezji i Gospodarki Przestrzennej, UW-M Olsztyn (typescript).

Bravo-Moncayo, L., Naranjo, J.L., García, I.P., Mosquera, R. (2017). Neural based contingent valuation of road traffic noise. Transportation Research, Part D 50, 26-39.

Masters, T. (1996). Sieci neuronowe w praktyce. Programowanie w języku $C++$. Warszawa: Wydawnictwo Naukowo-Techniczne.

Morris, A. (2009). Living on the margins: Comparing older private renters and older public housing tenants in Sydney, Australia. Housing Studies, 24 (5), 693-707.

Muczyński, A. (2006). Ocena rynkowej adekwatności czynszu najmu w gminnych zasobach mieszkaniowych. Studia i Materiały Towarzystwa Naukowego Nieruchomości, 14 (1), $159-175$.

Muczyński, A. (2009). Grupowanie nieruchomości wspólnot mieszkaniowych z wykorzystaniem sieci Kohonena. Acta Scientiarum Polonorum, Administratio Locorum, 8 (4), 5-15.

Muczyński, A., Kołek, M. (2007). Modelowanie czynszu najmu lokali użytkowych gminy z zastosowaniem sztucznych sieci neuronowych. Acta Scientiarum Polonorum, Administratio Locorum, 6 (2), 55-67.

Osowski, S. (1996). Sieci neuronowe w ujęciu algorytmicznym. Warszawa: Wydawnictwo Naukowo-Techniczne.

StatSoft (2001). Wprowadzenie do sieci neuronowych. Statsoft Polska Sp. z o.o., Kraków, www. statsoft.pl.

Tadeusiewicz, R. (1993). Sieci neuronowe. Warszawa: Akademicka Oficyna Wydawnicza RM.

Walacik, M. (2016). Analiza rynku najmu lokali użytkowych miasta Olsztyna w 2015 roku (expertise not published).

Witkowska, D. (2002). Sztuczne sieci neuronowe i metody statystyczne. Warszawa: Wydawnictwo Beck.

Wiśniewski, R. (1999). Metodyczne i praktyczne aspekty zastosowania sztucznej inteligencji $w$ taksacji powszechnej. Doctoral thesis performed under the direction of prof. R. Źróbek. Wydział Geodezji i Gospodarki Przestrzennej. UW-M Olsztyn (typescript). 